\title{
The Economic Crisis in Europe and its Consequences
}

Zaim Korsi

Dashurie Zenelhasani

Arzena Korsi

University of Aleksander Moisiu

Abstract:

\begin{abstract}
European economic growth is one of the major influences on the progress of the economy in the countries included in it. It has been a stimulus for the development of these countries, thus adding their neighbors' economic improvement of the country. The inclusion of these countries in economic growth has impacted pricing and the development of innovation and new in Europe technology. This thing helps in achieving the highest standards. Its coverage is an overwhelming contrast crisis that was reflected in the world in 2008. Duhet said that the effects of the crisis continue to be still visible in the livelihood of citizens and businesses.Edmund Phelps has proposed a rule on the establishment of high standards for the livelihood of citizens, in which specifies how many people have to work, conserve and invest today in order to be more sure which will be the future economy. This is called "Golden roles". But what are challenges that still confronts us economic crisis? How difficult it is now for businesses to apply the theory of Jim Collins, Good to Great? This article aims to reflect the economic situation in the EU countries, as well as laying economy recommendation that these countries will faced tomorrow. How difficult is to identify the companies that can make a Leap to develop their business? What are these difficulties? Is there a solution for them?
\end{abstract}

Keywords: Global crises, the risk of interest, IMF, EU

\section{The global crises}

The first sign of crises was in 2003 when USA housing markets expended because interest rates were low. This become serious in the middle of 2004, when US federal reserve raised interest rates to 5.25 percent.

The interest of mortgage before this has been low then 1 percent. In 2007 more than 100 mortgage lenders went bankrupt. The investors now know the dept risk but they could not adsorb the losses.

The crisis spread out the USA. The IKB Deutsche Industrie bank in Germany, BNP Paribas in France and Macquarie Bank in Australia faced with huge losses. Some banks and financial institutions received massive injection of public money. Central banks in us, Japan end EU inject liquidity into global financial system. This situation made EU and Us to lend from each other because they didn't want to show the sign of a credit risk. This would be a big problem for them. Even the crises origined in US, In Europe, banks and financial institutions were affected by losses related to mortgage investment.

Three important policy lessons from crises were:

1. in a poorly financial system banks and financial institutions can include in reckless lending to earn fees and quit profits without

2. Carrying for borrowers. This is completely true, and you can see it in Albania banking market.

3. The crises have showed that the impact of the risk in economy is explored in many countries.

4. Poorly regulated rating agencies have become a hazard to financial stability. The facts of facing in the risk of interest have made the number of borrowers slowdown.

\section{The financial costs in Europe, India and UK}

The markets are illiquid since the period of crisis.

The important role in the market and in the global economy plays private equity firms. We can think for Blackstone Group, Bain Capital or Texas Pacific Group, and we know that these company menage assets that worth billions and billions 
dollars. They control over 1 million workers. What can happen with the global economy IF one of them closed the doors of developing the activity?!

The crises has affected negatively in the global private equity industry. They have difficulties in borrowing money and in their portfolio. We can't say it for India or Asia. The profit from the private funds raise from 30 to $60 \%$ in 2007 . What happen in India in 2009?

In 2009 current account deficit touched 29.8 billion dollar against 15.7 billion dollar in 2007. This have been financed by large capital inflows in the form of portfolio investment. India also runs a perennial fiscal deficit.

The support that the government gives the bank sector in UK was 1.2 trillion pound. We must say that this happened even in the other country.

Jorge Nascimennto Rodriguez has estimated the total cost of global financial crises at 69 trillion dollar. As banks with bad loans tend to make them less, we should raise the performing loans in the markets.

In Croatia domestic economy is shrinking since the crises. This has increase the budget deficit and the number of unemployed

\section{IMF in the global crises}

By Simon Johnson, former chief economist of IMF, financial industry's share in total profit in 1973-1985 was $16 \%$ and when the crises come 41 of profits went to financial industry.

In UK the share from 8.3\% in 2007 went in 5.3 in 2001.

In 2006 global investment bank like JP Morgan Chase picked up 12.8 billion dollars in fees from private equity firms, but in 2007 they picked up only 8.4 billion dollars.

According to IMF: Divergent growth in the countries and monetary policies have increased tension in global financial markets and have caused a big risk at private company in growing their activities. This situation is a result of the weakness in legacy. The bank of Japan and the European Central Bank have pursued bold monetary policies to stability the disinflationary pressure.

And this strategy has worked and we see a good economic situation. According to report the financial stability risks have risen since the October 2015.

EU has earmarked 30 billion euro to support small business, also European Bank has allocated 1 billion eurofor controlling the credit risk. According to report the financial stability risks have risen since the October 2015.

In Europe in 2007-2009, IMF-international monetary fund has estimated that more than 1.3 trillion dollars in bad loans was written off. In the other side Asia and India are raising their economy. The investment in India have been higher, even Blackstone Group operate in India. All the sector of industry like infrastructure, media, and sport have attracted more inheres from investors.

In 2010, we can say that the regional economy raised as a result of net exports.

Unemployment in Serbia from 2008 to 2010 increase about $14.4 \%$ in 2008 while in 2010 we see the value about $20 \%$. In 2011 , unemployment reaches a record figure of $22.8 \%$.

While Bosje Herzegovina reaches a percentage of $27.2 \%$, Bulgaria and Romania have maintained the level of unemployment at $6 \%$.This percentage was attributed mostly to youth and non- participation of women.

\section{What will happen with our economy in the future year?!}

Policymakers should encourage banks to deal with their bad loans and ensure more efficient legal and institutional frameworks to spread up this process. They should to strengthen market liquidity and complete financial regulatory reforms 
/IMF. From this we can say that the problems in the Europe economy are bad loans that in fact were in a large number in period of crises.

Managing the risk of interest it's a big challenge for these countries. They have to control the banks operation with the fiscal policy. What can we say for the situation in Greece, or in the Ukraine? For sure they are a big risk for a global economy.

The best way to contribute in financial stability is putting in place policies that minimize the problems like interest risk and the problem situation in countries like Africa, Ukraine and Greece.

Supporting in developing small businesses would be a policy that will reduce the impact of the crisis in the economy, this because they occupy about $80 \%$ of employers. Strategy that the European Union is following is supporting this business and reducing bureaucracy. This strategy can increase GDP / in up to $1.4 \%$ and the conserve about 7.6 billion euro. We can mention Germany, which has changed the law for supporting citizens for opening new businesses .In Slovenia now we can register a business for only 3 days. Belgium, Finland, Spain, UK, Ireland have taken measures to overlap failure procedures.

\section{References:}

[1] http://www.ebrd.com/home - European Bank for Reconstruction and Development

[2] IMF-International Monetary Fund-Global Financial Stability risk

[3] INSTAT-Instituti I Statistikave

[4] Jim Collins-Good to Great

[5] Sherif Bundo,Evelyne Lande-Kontailitet Financiar 